\title{
Tannin Extraction from the Bark of Pinus oocarpa var. oocarpa with Sodium Carbonate and Sodium Bisulfite
}

\author{
Michel Cardoso Vieira ${ }^{1}$, Roberto Carlos Costa Lelis ${ }^{1}$, \\ Bruno Couto da Silva ${ }^{2}$, Gisely de Lima Oliveira ${ }^{2}$
}

${ }^{1}$ Departamento de Produtos Florestais, Instituto de Florestas, Universidade Federal Rural do Rio de Janeiro - UFRRJ

${ }^{2}$ Engenharia Florestal, Instituto de Florestas, Universidade Federal Rural do Rio de Janeiro - UFRRJ

\begin{abstract}
Tannin Extraction from the bark of Pinus oocarpa var. oocarpa with sodium carbonate and sodium bisulfite. The objective of this study was to evaluate the tannin extraction potential taken from the bark of Pinus oocarpa var. oocarpa. Nine treatments were performed; the bark was submitted to extraction using water and water containing different concentrations of sodium carbonate and sodium bisulfite. The mixture was kept under reflux for two hours. The extracted contents, the polyphenol found in the extracts (Stiasny number), the tannin yield, the non-tannin yield and the tannin reactivity through UV method were all determined. The results have revealed that it is possible to obtain high tannin content (approximately 39\%) from the bark of Pinus oocarpa var. oocarpa by using water extraction when coupled with the addition of salt. The treatment having (8\%) of sodium carbonate provided a greater yield of condensed tannins, underlining the importance of utilizing this salt with this concentration during the extraction process. However, the extracts must be evaluated according to other important wood-gluing properties, such as viscosity and gel time.
\end{abstract}

Keywords: Pinus oocarpa, bark, tannins.

\section{Extração de Taninos da Casca de Pinus oocarpa var. oocarpa com Carbonato de Sódio e Bissulfito de Sódio}

\section{RESUMO}

O objetivo deste estudo foi avaliar o potencial de extração de tanino retirado da casca de Pinus oocarpa var. oocarpa. Nove tratamentos foram realizados e a casca foi submetida à extração usando água e contendo diferentes concentrações de carbonato de sódio e bissulfito de sódio. A mistura foi mantida sobre refluxo, durante duas horas. Do conteúdo extraído, os polifenóis presentes nos extratos(número Stiasny), o teor de tanino, o teor de tanino e não reatividade de taninos pelo método UV foram determinados. Os resultados revelaram que é possível obter alto teor de tanino (aproximadamente 39\%) da casca de Pinus oocarpa var. oocarpa, usando a extração da água quando combinada com a adição de sal. O tratamento com (8\%) de carbonato de sódio proporcionou a maior produção de taninos condensados, evidenciando a importância de se utilizar este sal com esta concentração durante o processo de extração. No entanto, os extratos devem ser avaliados de acordo com outras importantes propriedades de colagem de madeira, tais como a viscosidade e o tempo de formação de gel.

Palavras-chave: Pinus oocarpa, casca, taninos. 


\section{INTRODUCTION}

Tannins are comprised in a group of substances occurring in various higher plant species, having the capacity to transform animal skins and hides into leather. The process is achieved associating the hydroxyl groups of tannins with the peptide bonds of amino acids present in animal protein, known as collagen (Haslam, 1966). Besides the tanning action, tannin solutions have other purposes, including: manufacturing of tiles and floors; assisting the drilling of oil wells; acting as dispersants and flocculants, amongst others (Poser \& Gosman, 1990).

According to Pizzi (1983), the term "tannin" has been frequently adopted to define two different groups of chemical compounds of phenolic nature: hydrolysable tannins and condensed tannins. Hydrolysable tannins can be considered polyesters derived from glucose, these can be classified into two categories: a) gallotannins, which release gallic acid and its derivatives when submitted to acid hydrolysis; and b) ellagitannins, which upon hydrolysis release ellagic acid and valonic acid - ellagic acid being the most significant (Clifford \& Scalbert, 2000).

Condensed tannins consist of flavonoid units, known as flavan-3-ols (catechins) and flavan3,4-diols (leucoantocyanidins) (Pizzi, 1983; Schofield et al., 2001). These present various degrees of condensation, do not suffer hydrolysis and precipitate with formaldehyde and hydrochloric acid, according to the Stiasny reaction (Roffael \& Dix, 1994). The condensed tannins are most commonly presented as polymers, with an average degree of condensation ranging from 4 to 12 flavonoid units.

Plants have a natural ability to defend themselves against their natural enemies - this defensive capability is linked to the presence of tannins. Such compounds are responsible for the astringency of many fruits and plants, due, in part, to the complexes formed between tannins and proteins, the basis for some of their biological properties including the control of insects, fungi and bacteria (Scalbert, 1992; Luck et al., 1994; Aerts et al., 1999). Concerned with the action of hydrolysable tannins in herbivores, Guimarães-Beelen et al. (2006) reported that said compounds may be involved in the animal's digestive process, hampering it, due to the complexes formed between tannins and certain proteins involved with the production of digestive enzymes.

Tannins can range between 2 and $40 \%$ of the dry bark of many species (Hergert, 1989). Such values may render the product economically viable for industrial utilization when the range of possible applications for tannins is considered. Tannins are most commonly obtained from the wood and bark of certain deciduous trees, since, except for their bark, coniferous trees possess only a small amount of tannins. The bark of Picea abies can contain up to $15 \%$ tannin. Some mangrove species can possess values of up to $35 \%$, and, in the case of the Quebracho tree (Schinopsis balance Engl.), the tannin content varies between 30 and 35\% (Roffael \& Dix, 1994). Weismann \& Ayla (1980), working with the conifer bark extracted, using hot water, ascertained levels between 25 and $30 \%$ of extractives, which possessed high levels of tannins.

In some species of pine, polyphenols may appear in the form of phlobaphens, this form being highly condensed and insoluble in water. In literature, there are reports indicating the bark can also contain large amounts of non-phenolic compounds (Dix \& Marutzky, 1982). According to Roux et al. (1975), when extracting the bark with weak alkaline solutions or in the presence of sulfite and bisulfite, the pyran rings of polyphenols are partly cleaved with the formation and deposition of carboxylic groups and sulfonic acids. Therefore, the solubility of phlobaphens increases considerably.

Tannins are also used to substitute for synthetic resins thanks to its characteristic to precipitate with formaldehyde, forming a polymer of rigid structure (Gonçalves \& Lelis, 2000). The reaction of tannins with formaldehyde represents the basis for its role as an adhesive, forming polycondensates of high molecular weight (Roffael \& Dix, 1994). The reaction of polyphenols with formaldehyde enables its use in the manufacture of wood panels under normal gluing and pressing conditions (Prasetya \& Roffael, 1991).

Tannins from the bark of the black wattle and the quebracho tree are considered to be the most important condensed tannins produced in industry. In Brazil, work involving tannins, including wood gluing, was initiated in the late 1970's and early 1980's 
(Coppens et al., 1980; Santana et al., 1981). However, only recently has this theme come to prominence again (Gonçalves, 2000; Tostes, 2003; Mori et al., 1999, 2000).

Among the botanical species, the genus Pinus possesses great potential for the extraction of tannins, since it covers much of the reforestation areas in Brazil. According to SBS (Sociedade..., 2007), approximately 3,000 companies in Brazil use pinewood in their productive processes, concentrating on the following products: sawn wood, cellulose, and paper and panels (plywood, MDF and OSB). Pine bark is a residue for the majority of the wood industries, presenting an environmental and economic challenge upon disposal (Borges et al., 1993).

The international market for tannin extracts of vegetable origin produces about 160,000 tons per annum (TPA), approximately 100,000 TPA originating from acacia plantations; the remainder is sourced from other species, including: Castanheira (Italian), Quebracho (Argentinean) and Tara (Peruvian). The TANAC S/A company, located in southern Brazil, is the largest vegetable extract producer in the world, having the capacity to produce 32,000 TPA of products. Another Brazilian company, SETA, has two factories having the capacity to produce 27,000 TPA. Production in Brazil is similar to numerous African countries, where the favorable climate allows for acacia forests. TANAC occupies 26,000 ha, cultivated close to the port in Rio Grande, in the State of Rio Grande do Sul, from where it is exported as residual firewood to Japan (Química, 2004).

In Brazil, work involving tannins from pine is still incipient. Perhaps the first study to address this topic was Ferreira (2004), having worked with eight pine species planted in Brazil. The author demonstrated that Pinus oocarpa and Pinus caribaea presented potential to supply tannins for wood gluing. A possible alternative for the extracted bark would be the extraction of tannins to produce wood glue, and the residue obtained after extraction could be burned for energy generation.

\subsection{Objective}

The objective of this study was to evaluate the tannin extraction from the bark of Pinus oocarpa var. oocarpa tree using water and water containing sodium carbonate and sodium bisulfite, aiming for partial or complete adoption as an adhesive in the manufacturing of wood panels.

\section{MATERIALS AND METHODS}

\subsection{Material}

Bark of Pinus oocarpa was collected from Fazenda Monte Alegre, Duratex, located in Agudos, Sao Paulo. All bark had been randomly chosen from five trees in two plots, with diameter at breast height (DBH) ranging between 15 and $40 \mathrm{~cm}$. Consequently, the trees were marked and their barks removed using a machete, and, as a standard, the removal of bark began at $\mathrm{DBH}$ all the way to the base of the standing trees. The material was then sent to the Laboratory of Wood Chemistry, Department of Forest Products and Institute of Forestry, to be fragmented in a hammer mill.

\subsection{Tannin extraction}

The material was extracted in a boiling flask under reflux for two hours having used a liquor/ bark ratio of 15:1. After extraction, the material was filtered under vacuum using a Büchner funnel. Each treatment was performed five times. The percentage of chemical products was calculated based on the dry weight of the barks. The treatments are schematized as follows:

- T1: Extraction with distilled water

- T2: Extraction with distilled water $+1 \% \mathrm{Na}_{2} \mathrm{CO}_{3}$

- T3: Extraction with distilled water $+5 \% \mathrm{Na}_{2} \mathrm{CO}_{3}$

- T4: Extraction with distilled water $+8 \% \mathrm{Na}_{2} \mathrm{CO}_{3}$

- T5: Extraction with distilled water $+10 \% \mathrm{Na}_{2} \mathrm{CO}_{3}$

- T6: Extraction with distilled water $+1 \% \mathrm{NaHSO}_{3}$

- T7: Extraction with distilled water $+5 \% \mathrm{NaHSO}_{3}$

- T8: Extraction with distilled water $+8 \% \mathrm{NaHSO}_{3}$

- T9: Extraction with distilled water $+10 \% \mathrm{NaHSO}_{3}$

\subsection{Determination of extraction properties}

For each treatment, the percentages of extractives and its properties were determined: percentage of condensed polyphenols as measured according to the Stiasny method (Stiasny Index - SI) and the UV 
method, content of tannins, content of non-tannins and $\mathrm{pH}$ value.

\subsection{Chemical characterization of polyphenols (tannins)}

The polyphenolic content was determined by the Stiasny reaction (Wissing, 1955; Lelis, 1995) and by the UV method (Roffael, 1976).

\subsection{Determination of polyphenols by the reaction of Stiasny}

After each extraction, an aliquot of $50 \mathrm{~mL}$ was added to a $250 \mathrm{~mL}$-round-bottom flask. In addition, $5 \mathrm{~mL}$ of hydrochloric acid and $10 \mathrm{~mL}$ of formaldehyde were added. This material was then kept under reflux for 30 minutes and later filtered and washed with distilled water in a Büchner funnel of known weight. The residue (tannin) was then placed in a drying oven at a temperature of $105+3{ }^{\circ} \mathrm{C}$ until mass stabilization. The percentage of condensed tannin contained in the extracts (Stiasny Index - SI) was determined by calculating the ratio between tannin mass and the mass of total extractives extrapolated to $50 \mathrm{~mL}$ and the result converted to a percentage (Equation 1):

$\mathrm{SI}=\frac{\tan \text { nin mass }}{\text { mass of total extractives }} \times 100$

\subsection{Determination of reactivity}

The UV method is based on the Stiasny reaction, using a before and after aliquot of the filtrate to react with hydrochloric acid and formaldehyde (Roffael, 1976). For each sample, an absorbance reading in a spectrophotometer was performed, before and after the reaction, to verify reactivity. The readings were performed at a wavelength of $280 \mathrm{~nm}$. The tannin reactivity was calculated coupled with the absorbance results from before and after the reaction.

\subsection{Determination of tannin content and non-tannin content}

To obtain the percentage of tannin in the bark, the Stiasny index was multiplied by the total amount of extractives and the result converted to a percentage.
The difference between extractive content and tannin content provided the percentage of non-tannins.

\section{8. $p H$ determination}

The $\mathrm{pH}$ of the solutions was obtained using a digital $\mathrm{pH}$ meter provided by QUIMIS. Measurements were conducted at room temperature and the value was registered after four minutes of electrode contact with the solution.

\subsection{Statistical analysis}

The design was completely randomized having five repetitions. The data referring to each test was subjected to variance analysis. Having rejected the null hypothesis, the F test was applied to the Scottknott test at a significance level of 5\% for comparison between mean values.

\section{RESULTS AND DISCUSSION}

Content of polyphenols (SI), percentage of extractives, tannins and non-tannins for different treatments.

Table 1 presents the mean values of the different bark treatment for content of polyphenols (SI), \% of extractives, tannins and non-tannins.

The Stiasny index (SI) represents the content of polyphenols (condensed tannins) existing in the extract. The results indicate that the distinct solvents used acted in an unequal manner in the solubility of polyphenol extracts. Generally, the treatments with varying proportions of sodium carbonate had higher values of Stiasny index over treatments with varying proportions of sodium bisulfite. The addition of sodium carbonate favored higher quantities of extractives and tannins (T2, T3, T4, T5).

The extractives content found in the treatment with water (24.84\%) was superior to that found by Ferreira (2004), also working with the bark of Pinus oocarpa var. oocarpa. The values of Stiasny index (SI), percentage of extractives, percentage of tannins and non-tannins found in treatment T3 were slightly superior to those found by Ferreira (2004).

It has been observed that treatment $\mathrm{T} 5$ presented a high yield of tannins. Nevertheless, the percentage of non-tannins was notably high, too. High 
Table 1. Mean values of the Stiasny number (SI), \% of extractives, $\%$ of tannins and \% of non-tannins in the bark of Pinus oocarpa var. oocarpa.

Tabela 1. Valores médios do Número de Stiasny (NS), \% de extrativos, \% de taninos e \% de não taninos na casca de Pinus oocarpa var. oocarpa.

\begin{tabular}{ccccc}
\hline Treatment & SI (\%) & \% Extractives & \% Tannins & \% Non-tannins \\
\hline T1 & $65.56^{\mathrm{C}}$ & $24.84^{\mathrm{F}}$ & $16.24^{\mathrm{F}}$ & $8.60^{\mathrm{B}}$ \\
T2 & $85.72^{\mathrm{A}}$ & $30.94^{\mathrm{D}}$ & $26.40^{\mathrm{D}}$ & $4.54^{\mathrm{C}}$ \\
\hline T3 & $89.70^{\mathrm{A}}$ & $35.74^{\mathrm{C}}$ & $32.10^{\mathrm{C}}$ & $3.69^{\mathrm{C}}$ \\
T4 & $90.54^{\mathrm{A}}$ & $43.92^{\mathrm{B}}$ & $39.74^{\mathrm{A}}$ & $4.18^{\mathrm{C}}$ \\
\hline T5 & $74.82^{\mathrm{B}}$ & $48.84^{\mathrm{A}}$ & $36.50^{\mathrm{B}}$ & $12.34^{\mathrm{A}}$ \\
T6 & $84.64^{\mathrm{A}}$ & $19.86^{\mathrm{G}}$ & $17.56^{\mathrm{F}}$ & $2.30^{\mathrm{C}}$ \\
\hline T7 & $72.28^{\mathrm{B}}$ & $26.70^{\mathrm{E}}$ & $19.28^{\mathrm{E}}$ & $7.42^{\mathrm{B}}$ \\
\hline T8 & $74.62^{\mathrm{B}}$ & $26.52^{\mathrm{E}}$ & $19.82^{\mathrm{E}}$ & $6.70^{\mathrm{B}}$ \\
\hline T9 & $84.00^{\mathrm{A}}$ & $23.28^{\mathrm{F}}$ & $19.48^{\mathrm{E}}$ & $3.80^{\mathrm{C}}$ \\
\hline
\end{tabular}

Means followed by the same letter, inside the same column, don't differ among themselves by Scott-knott to $5 \%$ of level of significance.T1: Extraction with distilled water,T2: Extraction with distilled water $+1 \% \mathrm{Na}_{2} \mathrm{CO}_{3}$, T3: Extraction with distilled water $+5 \% \mathrm{Na}_{2} \mathrm{CO}_{3}$, T4: Extraction with distilled water $+8 \% \mathrm{Na}_{2} \mathrm{CO}_{3}$, T5: Extraction with distilled water $+10 \% \mathrm{Na}_{2} \mathrm{CO}_{3}$, T6: Extraction with distilled water $+1 \% \mathrm{NaHSO}_{3}$, T7: Extraction with distilled water $+5 \% \mathrm{NaHSO}_{3}$, T8: Extraction with distilled water $+8 \% \mathrm{NaHSO}_{3}$, T9: Extraction with distilled water $+10 \% \mathrm{NaHSO}_{3}$.

percentage of non-tannins may impair the use of the extract as an adhesive, mainly affecting its viscosity (Pizzi, 1994).

\subsection{Polyphenol content by ultraviolet method $(U V)$}

Table 2 presents the mean values of phenol content using the UV method.

The quantification of polyphenols through UV absorption can be considered more effective than the Stiasny method, because it also accounts for the polyphenols that react with formaldehyde and do not precipitate.

Through this method, it is observed that the mean values obtained for reactivity were high, indicating high reactivity between polyphenols (tannins) from the bark of Pinus oocarpa var oocarpa. Statistically, there were significant variations between the results obtained in the extraction with distilled water compared to other forms of extraction.

Ferreira (2004) obtained a tannin reactivity of 99.03\% in the water extract of Pinus oocarpa var oocarpa with $5 \%$ sodium sulfite, this being similar to the value obtained in this study (94.51\%). Souza (2006) obtained a tannin reactivity of $52.50 \%$ in a water extract of Eucalyptus pellita with $5 \%$ sodium sulfite, and Teodoro \& Lelis (2003) acquired a tannin reactivity of $63.7 \%$ using only water, less than the result found in this study (85.32\%).
Table 2. Mean values of polyphenol content from the bark of Pinus oocarpa var. oocarpa using the UV method.

Tabela 2. Valores médios do teor de polifenóis pelo método ultravioleta (UV) na casca de Pinus oocarpa var. oocarpa.

\begin{tabular}{cc}
\hline Treatment & Reactivity (UV) \% \\
\hline T1 & $85.32^{\mathrm{B}}$ \\
T2 & $99.25^{\mathrm{A}}$ \\
T3 & $94.51^{\mathrm{A}}$ \\
T4 & $96.90^{\mathrm{A}}$ \\
T5 & $95.57^{\mathrm{A}}$ \\
T6 & $98.09^{\mathrm{A}}$ \\
T7 & $99.21^{\mathrm{A}}$ \\
T8 & $99.50^{\mathrm{A}}$ \\
T9 & $98.29^{\mathrm{A}}$ \\
\hline
\end{tabular}

Means followed by the same letter, inside the same column, don't differ among themselves by Scott-knott to $5 \%$ of level of significance.T1: Extraction with distilled water, T2: Extraction with distilled water $+1 \% \mathrm{Na}_{2} \mathrm{CO}_{3}$, T3: Extraction with distilled water $+5 \% \mathrm{Na}_{2} \mathrm{CO}_{3}$, T4: Extraction with distilled water $+8 \% \mathrm{Na}_{2} \mathrm{CO}_{3}$, T5: Extraction with distilled water $+10 \% \mathrm{Na}_{2} \mathrm{CO}_{3}$, T6: Extraction with distilled water $+1 \% \mathrm{NaHSO}_{3}$, T7: Extraction with distilled water $+5 \%$ $\mathrm{NaHSO}_{3}, \mathrm{~T} 8$ : Extraction with distilled water $+8 \% \mathrm{NaHSO}_{3}$, T9: Extraction with distilled water $+10 \% \mathrm{NaHSO}_{3}$.

\section{2. $p H$ of extracts}

Table 3 presents the mean values obtained for the $\mathrm{pH}$ of extracts.

The $\mathrm{pH}$ is of great importance in tannin reactivity, for only in an acidic $\mathrm{pH}$ can the condensation 
Table 3. Mean $\mathrm{pH}$ levels of extract acquired from the bark of Pinus oocarpa var. oocarpa.

Tabela 3. Valores médios encontrados para o valor de $\mathrm{pH}$ dos extratos da casca de Pinus oocarpa var. oocarpa.

\begin{tabular}{cc}
\hline Treatment & pH \\
\hline T1 & $3.01^{\mathrm{F}}$ \\
T2 & $5.53^{\mathrm{D}}$ \\
T3 & $7.50^{\mathrm{C}}$ \\
T4 & $8.06^{\mathrm{B}}$ \\
\hline T5 & $8.74^{\mathrm{A}}$ \\
T6 & $3.20^{\mathrm{F}}$ \\
T7 & $3.20^{\mathrm{F}}$ \\
T8 & $3.52^{\mathrm{E}}$ \\
T9 & $3.32^{\mathrm{E}}$ \\
\hline
\end{tabular}

Means followed by same letter, inside the same column, don't differ among themselves by Scott-knott to 5\% of level of significance.T1: Extraction with distilled water, T2: Extraction with distilled water $+1 \% \mathrm{Na}_{2} \mathrm{CO}_{3}$, T3: Extraction with distilled water $+5 \% \mathrm{Na}_{2} \mathrm{CO}_{3}$, T4: Extraction with distilled water $+8 \%$ $\mathrm{Na}_{2} \mathrm{CO}_{3}$, T5: Extraction with distilled water $+10 \% \mathrm{Na}_{2} \mathrm{CO}_{3}$, T6: Extraction with distilled water $+1 \% \mathrm{NaHSO}_{3}$, T7: Extraction with distilled water $+5 \% \mathrm{NaHSO}_{3}$, T8: Extraction with distilled water $+8 \% \mathrm{NaHSO}_{3}$, T9: Extraction with distilled water $+10 \%$ $\mathrm{NaHSO}_{3}$.

reaction between tannins and formaldehyde take place, resulting in the polymerization of the resin.

It has been observed that the addition of salts in the extraction process increased the $\mathrm{pH}$ of extracts, indicating that there were significant variations between the results. The results obtained in the treatment with pure water presented the lowest $\mathrm{pH}$ values, demonstrating the acidic nature of tannins in water extracts. Ferreira (2004) obtained a pH value in the water extract of Pinus oocarpa var. oocarpa of 3.35 , similar to the value acquired in this study (3.01).

However, with the addition of higher concentrations of sodium bisulfite, there was an increase in the $\mathrm{pH}$ value, yet the extracts still presented an acidic nature. The higher mean $\mathrm{pH}$ values (above 7.0) occurred with the addition of sodium carbonate. Ferreira (2004) obtained a pH value of 7.21 in water extract with $5 \%$ sodium sulfite of Pinus oocarpa var. oocarpa, nearing the value acquired in this study (7.50).

\section{CONCLUSIONS}

The addition of sodium carbonate to the extraction process enhanced the solubilization of greater quantities of condensed tannins.
The addition of higher percentages of sodium bisulfite did not result in higher percentages of tannins.

Treatment with $8 \%$ sodium carbonate provided the highest yield of condensed tannins, underlining the importance of utilizing this specific salt concentration in the extraction process. However, the extracts must be evaluated according to other important bonding properties, including viscosity and gel time.

\section{SUBMISSION STATUS}

Received: 11/11/2010

Accepted: 28/01/2011

Abstract published online: 28/02/2011

Full paper published: 31/03/2011

\section{CORRESPONDENCE TO}

\section{Michel Cardoso Vieira}

Departamento de Produtos Florestais, Instituto de Florestas, Universidade Federal Rural do Rio de Janeiro - UFRRJ, BR-465, Km 7, CEP 23890-000, Seropédica, RJ, Brasil e-mail: mceflorestal@ig.com.br

\section{REFERENCES}

Aerts TJ, Barry TN, McNabb WC. Polyphenols and agriculture: beneficial effects of proanthocyanidins in forages. Agriculture, Ecosystems and Environment 1999; 75:1-12. http://dx.doi.org/10.1016/S01678809(99)00062-6

Borges AS, Ciniglio G, Brito JO. Considerações energéticas e econômicas sobre resíduos de madeira processada em serrarias. In: Anais do Congresso Florestal Brasileiro; 1993; Sociedade Brasileira de Engenheiros Florestais; 1993. p. 603-605.

Clifford MN, Scalbert A. Ellagitannins - nature, occurrence and dietary burden. Journal of the Science and Food Agriculture 2000; 80:1118-1125.http://dx.doi.org/10.1002/ (SICI) $1097-0010(20000515) 80: 7<1118:$ :AID JSFA570>3.0.CO;2-9

Coppens H, Santana MAE, Pastore Junior F. Tanninformaldehyde adhesive for exterior-grade plywood and 
particleboard manufacture. Forest Product Journal 1980; 30(4):38-42.

Dix B, Marutzky R. Untersuchungen zur Gewinnung von Polyphenole aus Nadelholzrinden. Holz als Rohund Werkstoff 1982; 41:45-50. http://dx.doi.org/10.1007/ BF02612230

Ferreira ES. Utilização dos polifenóis da casca de pinus para produção de adesivos para compensados [dissertação]. Seropédica, RJ: Universidade Federal Rural do Rio de Janeiro; 2004.

Gonçalves CA, Lelis RCC. Avaliação do teor de tanino condensáveis de cinco de leguminosas arbóreas. In: Anais do VI Congresso e Exposição Internacional Sobre Florestas; 2000; Porto Seguro - BA; 2000. p. 393-394.

Gonçalves CA. Utilização do tanino da madeira de Mimosa caesalpiniaefolia Bentham (Sabiá) como matéria prima alternativa para a produção de adesivos [dissertação]. Seropédica, RJ: Universidade Federal Rural do Rio de Janeiro; 2000.

Guimarães-Beelen PM, Berchielli TT, Buddington R, Beelen, R. Efeito dos taninos condensados de forrageiras nativas do semi-árido nordestino sobre o crescimento e atividade celulolítica de Ruminococcus flavefaciens FD1. Arquivo Brasileiro de Medicina Veterinária e Zootecnia 2006; 58(5):910-917.

Haslam E. Chemistry of vegetable tannins. London: Academic; 1966.

Hemingway RW. Adhesives from southern pine bark - a review of past and current approaches to resin formulation problems. Madison/Wisconsin, USA: Forest Product Research Society; 1978. p. 443-457.

Hergert HL. Condensed Tannins in adhesives: Introduction and historical perspectives. In: Hemingway RW, Conner AH, Branham SJ. Adhesives from renewable resources. Washington, D.C.: American Chemical Society; 1989. p. 155-171. http://dx.doi. org/10.1021/bk-1989-0385.ch012

Lelis RCC. Zur Bedeutung der Kerninhaltsstoffe obligatorisch verkernter Nadelbaumarten bei der Herstellung von feuchtbeständigen und biologisch resistenten Holzspanplatten, am Beispiel der Douglasie (Pseudotsuga menziesii Mirb. Franco) [tese]. Forstliche Fakultät der Universität Göttingen; 1995.

Luck G, Liao H, Murray NJ, Grimmer HR, Warminski EE, Williamson MP et al. Polyphenols, Astrigency and Proline-Rich Proteins. Phytochemistry 1994; 37:357-371. http://dx.doi.org/10.1016/0031-9422(94)85061-5
Mori CLSO, Mori FA, Pimenta AS, Melo VM Influência da temperatura, tipos e concentrações de sais inorgânicos no rendimento em taninos das cascas de Eucalipytus. In: Anais do VI Congresso e Exposição Internacional Sobre Florestas; 2000; p. 408.

Mori FA, Vital BR, Lucia RM, Valente OF, Pimenta AS. Utilização de resinas à base de taninos das cascas de Eucalyptus grandis w. Hill ex Maiden na produção de painéis compensados. Revista Árvore 1999; 23:455-461.

Pizzi A, Stephanou A. Fast vs. Slow-reacting non modified tanin extracts for exterior particleboard adhesives. Holz als Roh-und Werkstoff 1994; 52(218-222). http://dx.doi.org/10.1007/BF02619095

Pizzi A. Wood adhesives: chemistry and technology. New York: Marcell Dekker; 1983.

Poser GL von, Gosmann G. Acácia-Negra. Ciência Hoje 1990; 11(63):68-70.

Prasetya B, Roffael E. Neuartige Charakterisierung von natürlichen Polyphenolen hinsichtlich ihrer Vernetzbarkeit. Holz als Roh-und Werkstoff 1991; 49:481-484. http://dx.doi.org/10.1007/BF02619478

Quimica - Especialização também atinge o curtimento [cited 2009 abr. 15]. 2004. Available from: www. quimicaederivados.com.br/revista/qd423/couro5.htm.

Roffael E, Dix B. Tannine als Bindemittel für Holzwerkstoffe. Holz-Zentralblatt 1994; 120(6): 90-93.

Roffael E. Die Formaldehydabgabe von Spanplatten und anderen Holzwerkstoffen. Stuttgart: DRW-Verlag; 1983.

Roffael E. Über die Reaktivität von wäßrigen Rindenextrakten gegenüber Formaldehyd. Adhäsion 1976; 20(11):306-311.

Roux DG, Ferreira D, Hundt HKL, Malan E. Structure, stereochemistry and reactivity of natural condensed tannins as basis for their extented industrial application. Applied Polymer Symposium 1975, 28:335-353.

Santana MAE, Pastore Junior F. Adesivos de taninoformaldeído para aglomerados. Brasília: IBDF; 1981. Série técnica, 2 .

Scalbert A. Tannins in Woods and Their Contribution to Microbial Decay Prevention. In: Hemingway RW, Laks PE, editors. Plant Polyphenols. New York: Plenum Press; 1992.

Schofield P, Mbugua DM, Pell AN. Analysis of condensed tannins: a review. Animal Feed Science and Technology 2001; 91:21-40. http://dx.doi.org/10.1016/ S0377-8401(01)00228-0 
Sociedade Brasileira de Silvicultura - SBS. Fatos e números do Brasil florestal [cited 2009 nov. 05]. Available from: http://www.sbs.org.br/ FatoseNumerosdoBrasilFlorestal.pdf.

Souza JS. Utilização de adesivos à base de taninos de Acácia negra e Eucalyptus pellita para fabricação de painéis OSB [dissertação]. Seropédica, RJ: Instituto de Florestas, Universidade Federal Rural do Rio de Janeiro - UFRRJ; 2006.

Teodoro ÂS, Lelis RCA. Extração de taninos da casca de Eucallyptus pellita e avaliação de suas propriedades. Revista Universidade Rural, Série Ciências da Vida 2003; 23(2):65-70.
Tostes AS. Tanino da casca de Eucalyptus pellita F. Muell como fonte de adesivos para produção de chapas de madeira aglomerada [dissertação]. Seropédica, RJ: Instituto de Florestas, Universidade Federal Rural do Rio de Janeiro - UFRRJ; 2003.

Weissmann G, Ayla C. Die Verwendung von natürlichen Polyphenolen zur Herstellung von Holzleimen. Holz als Roh- und Werkstoff 1980; 38:54-249. http://dx.doi. org/10.1007/BF02616393

Wissing A. The utilization of bark II: Investigation of the Stiasny-reaction for the precipitation of polyphenols in Pine bark extractives. Svensk Papperstidning, 1955; 58(20):745-750. 